\title{
Achieving good environmental status in the Black Sea: scale mismatches in environmental management
}

\author{
$\underline{\text { Tim O'Higgins }}^{1}, \underline{\text { Andrew Farmer }}^{2}$, Georgi Daskalov ${ }^{3}, \underline{\text { Stale Knudsen }}^{4}$ and Laurence Mee $^{1}$
}

ABSTRACT. The Black Sea has suffered severe environmental degradation. Governance of the Black Sea region is complex and results in a series of scale mismatches which constrain management. This paper develops a simple classification of spatial scale mismatches incorporating the driver, pressure, state, welfare, response (DPSWR) framework. The scale mismatch classification is applied to two major environmental problems of the Black Sea, eutrophication and small pelagic fisheries. A number of scale mismatches are described and classified and potential solutions are identified.

Key Words: Black Sea; ecosystem approach; eutrophication; fisheries; marine strategy framework directive; scale mismatch

\section{ENVIRONMENTAL PROBLEMS AND GEOPOLITICS OF THE BLACK SEA}

The EU Marine Strategy Framework Directive (MSFD; European Commission 2008) aims at achieving or maintaining a Good Environmental Status (GEnS) by 2020 in the territorial waters of the EU Member States. To achieve GEnS, Member States have to develop marine strategies that contain programs of measures and that apply an ecosystem-based approach to the management of human activities. Achieving GEnS requires that a wide range of pressures on marine ecosystems are addressed, and the directive lists a series of 11 descriptors of GEnS including fisheries (Descriptor 3), nutrient pollution (Descriptor 5), amongst others. One of the challenges in meeting these wide ranging objectives is that the pressures, and the drivers of these pressures, can be subject to scale mismatches; they may arise outside of the jurisdiction of the Member State or outside of the territorial waters of the EU as a whole, or the pressures and states may occur at a scale too small to be effectively managed by the institutions responsible for them. The importance of addressing such mismatches in environmental management is increasingly recognised (Cash et al. 2006, Cumming et al. 2006, Henle et al. 2010, Veldkamp et al. 2011).

The Black Sea, bordered by six nations with different economic conditions, languages, cultures, and traditions; with six sets of national territorial waters; and with separate fisheries and environmental management arrangements (Duzgunes and Erdogan 2008), is an area of great geopolitical tension (Fig. 1). The Ukraine, Bulgaria, Romania, Russia, and Georgia were all centrally planned countries until the collapse of the Soviet system and are at various stages in the transition toward Western-style democracies. Because of its important strategic location in terms of international transport of oil and gas, the Black Sea was subject to intense pressure to open up trade and make new political alliances following the collapse of the Soviet Union and the end of the cold war (Vlad et al. 2009). Romania and Bulgaria acceded to NATO in 2004 and to the European Union in 2007. Turkey is also a NATO member and candidate for accession to the EU. The relatively sudden shift in the balance of power in the Black Sea region toward more western allied nations provides the context for regional cooperation. Although the accession of Romania and Bulgaria to the EU offers Europe strategic access to the Black Sea (Suárez de Vivero and Mateos 2006), this accession also brings with it obligations for environmental management and sustainable development under the MSFD and several other directives including the Water Framework Directive (WFD; European Commission 2000), the Urban Waste-Water Treatment Directive and the Nitrates Directive (Commission of the European Communities 1991 $a, b$ ). This situation was not limited to the six coastal countries of the Black Sea but also to the 11 noncoastal countries of the Danube Basin, nine of which are members or aspirant members of the EU and are obliged to comply with the WFD and EU farming policy (the Common Agricultural Policy).

Fig. 1. The Black Sea catchment (pale green) including the Danube catchment (pale red). Countries with territories within the catchment are named on the map, EU nations are shown with a thick white line, littoral states indicated by larger text. The Exclusive Economic Zones of the Black Sea littoral states are also indicated (black line). Waters under the jurisdiction of the EU Marine Strategy Framework Directive are shown in pale blue.

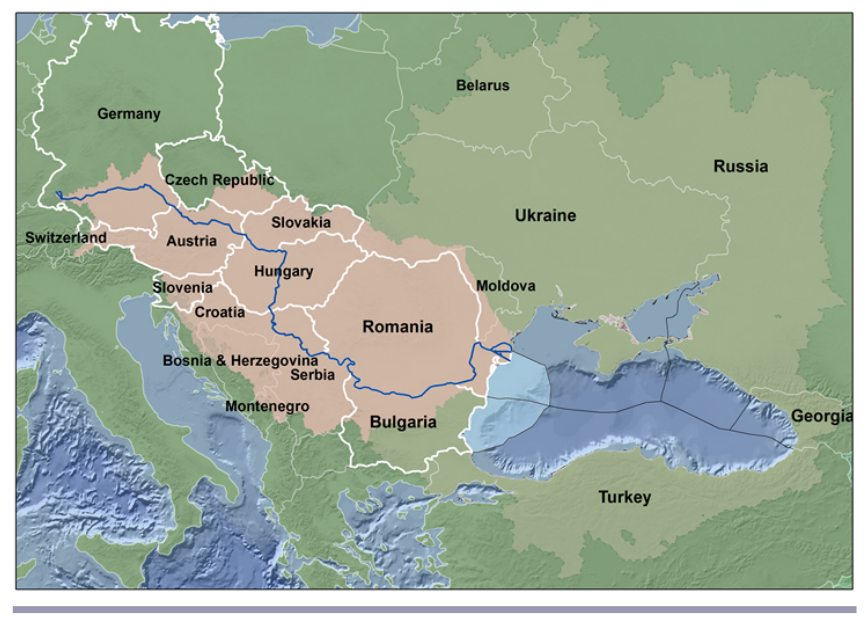

As a result of the clear urgency of the environmental problems of the Black Sea, in particular chemical pollution and severe eutrophication on the northwestern shelf, the Black Sea littoral states agreed in the early 1990s to the "Bucharest Convention against Pollution of the Black Sea," a legal convention whose implementation is promoted by the Black Sea Commission. This 
was backed up with a Ministerial level policy statement, the Odessa Declaration, signed in 1992 (Hey and Mee 1993). Negotiations for a new fisheries convention have been continuing at a very slow pace for the past two decades. The Commission's environmental strategy (BSC 2009) sets out a series of ecological quality objectives that include a commitment toward integrated management elimination of eutrophication and as a priority "[s] ustainable use of commercial fish stocks and other marine living resources" (BSC 2009). It is unclear, however, whether the obligations of the EU Member States, Romania and Bulgaria, under the MSFD can be met within a shared sea with differing political regimes even within the shared framework of the Black Sea Convention.

The geopolitical complexity of the Black Sea region poses a major challenge to achieving regional environmental goals. Understanding the specific spatial characteristics of individual environmental problems may help to illuminate potentially effective management strategies. The aim of this paper is identify spatial mismatches constraining marine environmental management in the Black Sea region and to explore the aspects of governance that can be improved to address these mismatches. A simple classification of scale mismatches (based on Cumming et al. 2006) is developed. Detailed driver, pressure, state, analysis for eutrophication and Black Sea fisheries are presented and the scale mismatch classification is applied. The mismatches are used to identify the qualities of a more effective management regime and associated governance.

\section{METHODS: DPSWR ANALYSIS AND DECISION SPACE ANALYSIS MAPS}

The driver, pressure, state, impact, response (DPSIR) cycle and its successors, modified DPSIR (mDPSIR; Langmead et al. 2009, Knudsen et al. 2010, Atkins et al. 2011) and DPSWR where the term impact is replaced with welfare (Cooper 2013), are well tested and widely used conceptual frameworks for analysis of social/ ecological problems including in marine systems (Borja et al. 2006, Langmead et al. 2009, Knudsen et al. 2010, Atkins et al. 2011); here we follow Cooper's DPSWR model (2013). Drivers are economic and social forces resulting from government policies, markets, and private industry. Pressures are the ways these drivers place demands upon ecosystems. Pressures are at the interface between the social and ecological components of the system, caused by the social part of the system, but occurring within the ecological part. State changes are environmental changes occurring to the ecosystem resulting from pressures. Welfare is the change in human welfare attributable to these state changes. The management response to a particular problem may then be directed toward any of the other elements (D, P, S, or W) in an effort to achieve a balance between the benefits of economic and social development and ecosystem costs (Cooper 2013).

Social-ecological scale mismatches occur where "human institutions do not map coherently on to the biogeophysical scale of a resource in space or time" (Cash et al. 2006). Despite considerable academic interest in the idea of scale mismatch (e.g., Cumming et al. 2006, Henle et al. 2010, Veldkamp et al. 2011) the concept is rather abstract and there is little evidence that the theory behind scale mismatch literature is being integrated into environmental policy (Kok and Veldkamp 2011). Figure 2 introduces a simple classification of scale mismatches based on the work of Cumming et al. (2006) and using the DPSWR information categories. By taking the response as the scale frame, mismatches may be classified relative to it, i.e., the spatial scale of an ecological problem (comprised of pressures and states) is either larger or smaller than the fixed scale of a specific response; we call these grain and extent mismatches, respectively. To facilitate communication of the drivers, pressures, state, welfare, and responses and potential mismatches of scale we have produced maps of the DPSWR elements which we call decision space analysis maps (See O'Higgins and Roth 2011).

Fig. 2. a) Illustration of the driver, pressure, state, welfare, response (DPSWR) framework showing the trade-off between the drivers of environmental state change and the changes in welfare caused by environmental change. See text for description of the DPSWR elements. b) A classification of scale mismatch. Extent mismatches occur when the pressure and state change lie partially or entirely outside the spatial domain of the response; grain mismatches occur when the spatial scale of the pressures is at too small a scale to be effectively managed by a Response mechanism.

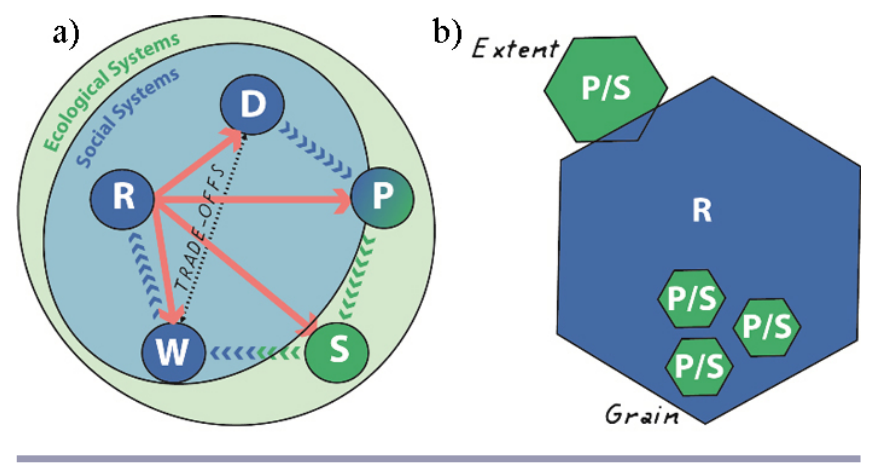

\section{RESULTS}

The Danube catchment nutrient management and eutrophication in the northwest shelf

Driven by the intensive agricultural production of centralized economies and receiving $70 \%$ of its nutrient load from the River Danube, the northwestern shelf of the Black Sea was experiencing primary symptoms of eutrophication by the 1970s (Bodeanu 2002, Mee et al. 2005). By the 1980s, secondary symptoms including hypoxia and mass mortality of benthic flora and fauna were occurring (Cociasu et al. 1996). The collapse of the centralized governments and the resulting deintensification of agriculture, the main driver of eutrophication, were followed by signs of recovery (Mee et al. 2005, Mee 2006; Fig. 3-inset graph).

The DPSWR components for eutrophication in the present period are summarised in Figure 2. The principal drivers for eutrophication in the northwest shelf of the Black Sea did not disappear with the collapse of the Soviet Union; agriculture is still a major activity and source of income in the lower Danube countries. Agricultural subsidies are prevalent throughout the EU nations in the Black Sea catchment with a total of almost $€ 32 \mathrm{bn}$ paid through the Common Agricultural Policy (CAP) to Danube catchment countries between 2008 and 2010, providing a driver of eutrophication (http://farmsubsidy.org). The other major driver of eutrophication, the production of wastewater, follows the level of human population within the catchment. 
Fig. 3. Decision Space Analysis map illustrating the main driver, pressure, state, impact, response (DPSIR) elements for the eutrophication in the Black Sea. Agricultural subsidy data are from 2009 (http://farmsubsidy. org). Fertilizer application within the Black Sea catchment for the year 2010 (as a proxy for diffuse nutrient pressure) was estimated from fertilizer consumption data (FAO 2012) and agricultural coverage data (Ramunkutty et al. 2008). Spatial extent of hypoxia and time-series data provided by Dr. Jana Friedrich.

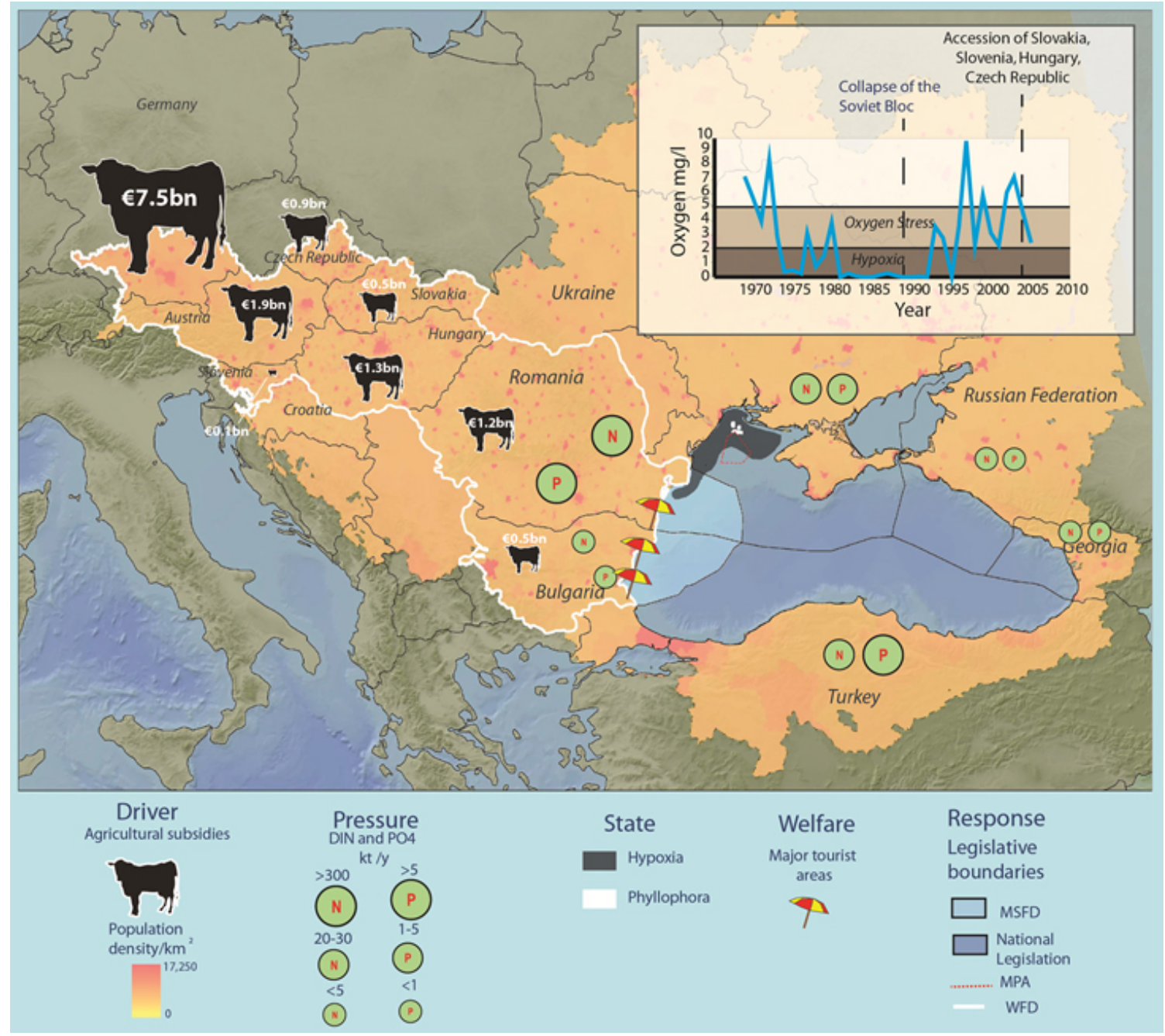

Nutrient pressures in the Danube catchment come from point and diffuse sources, reflecting the different drivers. The major point source is waste water (treated and untreated) and the principal diffuse source is run-off of agricultural fertilisers (ICPDR 2009). Modeling studies suggest that in the Danube catchment $86 \%$ of nitrogen emissions and $71 \%$ of phosphorus emissions now come from diffuse sources (ICPDR 2009).

The change in environmental state, evidenced by an increase in lower trophic level biomass and the resulting oxygen depletion, is mainly confined to the northwest shelf of the Black Sea, both in Romanian and Bulgarian waters and, outside European Union jurisdiction, in the Ukrainian shelf waters.

Although there is no direct measure of the economic value of the changes in human welfare caused by eutrophication, choice experiments have indicated considerable willingness to pay for improvements in water quality at a local level (Taylor and Longo 2010). Nations within the catchment have very different economic conditions with the wealthier nations such as Austria and Germany having a GDP per capita of more than 10 times that of the poorest country in the catchment, Moldova (Fig. 4).

Responses are in place in the Danube catchment to tackle the eutrophication problem, both at the EU level (see Fig. 3) through the WFD, the urban waste water treatment, and nitrates Directives, and at the regional level through the International Commission for the Protection of the Danube River (ICPDR). Over $€ 4$ bn was spent to reduce eutrophication in the period 2000-2005 (ICPDR 2007). The major investment was on improvements to waste water treatment facilities (€3.7bn), a technical solution which decouples the driver of waste water production from the pressures caused by nutrient loading. A further $€ 6.2 \mathrm{bn}$ is expected to be spent on urban wastewater 
treatment under the current joint Programme of measures which extends to 2015 (ICPDR 2012). However, for nitrogen limited offshore eutrophication under the jurisdiction of the MSFD, the major driver of eutrophication is agriculture and the associated diffuse nutrient pressures has received relatively little investment in the past (€0.1bn; ICDPR 2007) and although legislation is in place to reduce diffuse agricultural sources of nitrogen there are no firm budgets for reduction of diffuse nutrients (ICPDR 2012).

Fig. 4. GDP per capita (2012) for each of the nations in the Danube catchment (dark blue) and Black Sea catchment for comparison (light blue). The text above the bar shows the year of accession to the EU, F = founder member, $\mathrm{C}=$ candidate, $\mathrm{P}$ $=$ potential candidate, $\mathrm{N}=$ noncandidate (World Bank 2013).

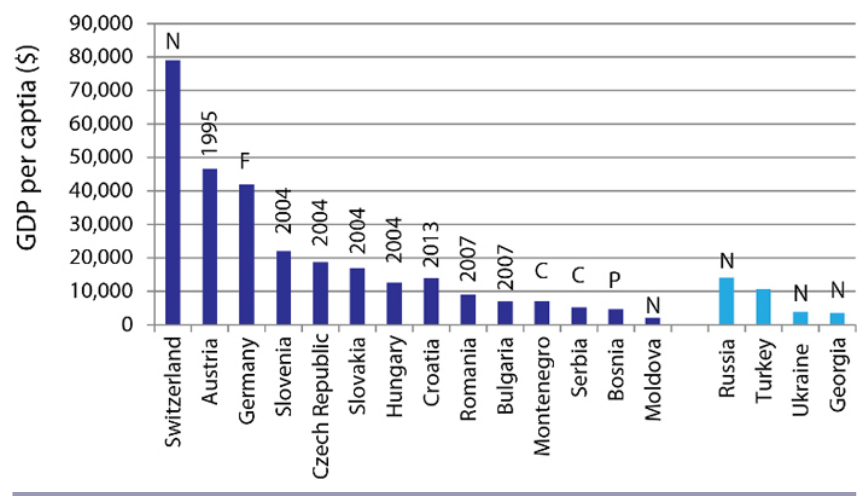

Considerations of the spatial scales of the DPSWR elements for nutrient pollution in the Danube catchment clearly indicate a grain scale mismatch. Although there are institutions in place with jurisdiction over the entire catchment area over which the pressure and state changes occur, enforcement and compliance are the two major barriers to achieving the goals of the ICPDR and the WFD (ICPDR 2007). Neither the ICPDR nor the EU can effectively respond to the diffuse agricultural pressures ultimately generated at the scale of individual farms. The Danube is the most international river catchment in the world and although EU regulation and structures for international cooperation (ICPDR) cover most or all of the spatial extent of the Danube catchment, at the national levels, the historical, economic, financial, and institutional differences between nations within the catchment and their differing histories of integration within the European Union (Fig. 4) result in differing capacities to respond to environmental problems at the requisite spatial scales.

There are also a number of other scale mismatches that affect the goal of avoiding eutrophication in the Black Sea. The first problem is a grain mismatch. The regional agreements for the Black Sea (Bucharest Convention, Black Sea Action Plan) involve the six Black Sea coastal countries; agreement on measures to control eutrophication under this framework include Russia, Georgia, and Turkey, countries that are less affected by the phenomenon and have a much smaller contribution to it than the other Black Sea countries and those of the Danube basin. That is, the state changes caused through reduced eutrophication occur on scales smaller than the scale of the international response. As a result, measures under the Bucharest Convention tend to be quite "soft," perhaps reflecting the reluctance of the eastern seaboard countries to agree to commit themselves to costly action that do not appear to bring concomitant benefits. In hindsight, it would have been much easier to set a scale for a regional political agreement from the outset that covered the Danube and Dnipro basins and the entire northwest shelf of the Black Sea, rather than negotiating this on a piecemeal basis.

\section{Management of small pelagic fisheries in the Black Sea}

Goulding et al. (2014) summarize the history of overfishing in the Black Sea, following the collapse of the larger, higher value species. The major fisheries currently being exploited in the Black Sea are those for small pelagic species, anchovy and sprat.

The major elements of the DPSWR for small pelagic fisheries in the Black Sea are shown in Figure 5. Figure 5 clearly illustrates the prominence of the Turkish fishery in the Black Sea both in terms of numbers of fishing ports and the landings of fish. Turkish demand for fish protein is the principal driver for Black Sea small pelagic fisheries.

Turkish fisheries constitute the major pressure on the fish stocks and make up about $80 \%$ by weight of the Black Sea catch (BSC 2008) with anchovy being by far the largest fishery followed by sprat (Daskalov and Ratz 2011). Legal fishing activities are mainly restricted to territorial waters though between 10 and $50 \%$ of the anchovy landed in Turkish ports is caught in Georgian waters (Özturk 2013; S. Knudsen, personal communication).

The main targeted stocks migrate throughout the Black Sea, and the state of the stocks is dependent on the condition of the spawning grounds found predominantly in the north and west and wintering areas found in the south and east as well as the level of fishing effort. Thus the state of the stock depends on activities throughout the region.

The small pelagic fisheries in the Black Sea are a considerable generator of welfare in the region. Historically the Black Sea's fisheries supported approximately 150,000 fishers, with up to two million dependents (including up- and downstream activities; Caddy 1992). Catch values were estimated to have declined by about US\$240 million over the decade up to the early 1990s. Knowler (2008) reported the modeling of nutrient-induced eutrophication and its impact on the commercial anchovy fishery in the Black Sea over two periods (1971-86 and 1987-93), showing that the effects of the nonindigenous comb jelly Mnemiopsis leydii reduced the profits of Black Sea anchovy fishery from over $\$ 17$ million per year to under $\$ 300,000$.

There is no jointly nominated scientific body responsible for delivering scientific advice, and no forum for coastal states to make decisions regarding the shared and straddling stocks, which comprise the most important commercial fisheries. Agreement on the text of a Legally Binding Document on Fisheries and the Conservation of Living Marine Resources (LBDFCLR) has been undermined by political disagreements, most recently in 2007 regarding EU desire to accede to the Bucharest Convention on the Protection of the Black Sea Against Pollution. Furthermore the different levels of engagement in global governance agreements related to exploitation of living marine resources (Table 1) also relieves governments from a commitment to seek agreements on fishing. In particular, the nonparticipation of Turkey in UNCLOS, while being the main fishing nation, is an obvious barrier. There is a clear incentive for Turkey to engage 
Fig. 5. Decision space analysis map for small pelagic fisheries in the Black Sea. Population in 2010, data from CIESIN et al. (2011). Landings data from Daskalov and Ratz (2011). Migration patterns redrawn from Ivanov and Beverton (1985).

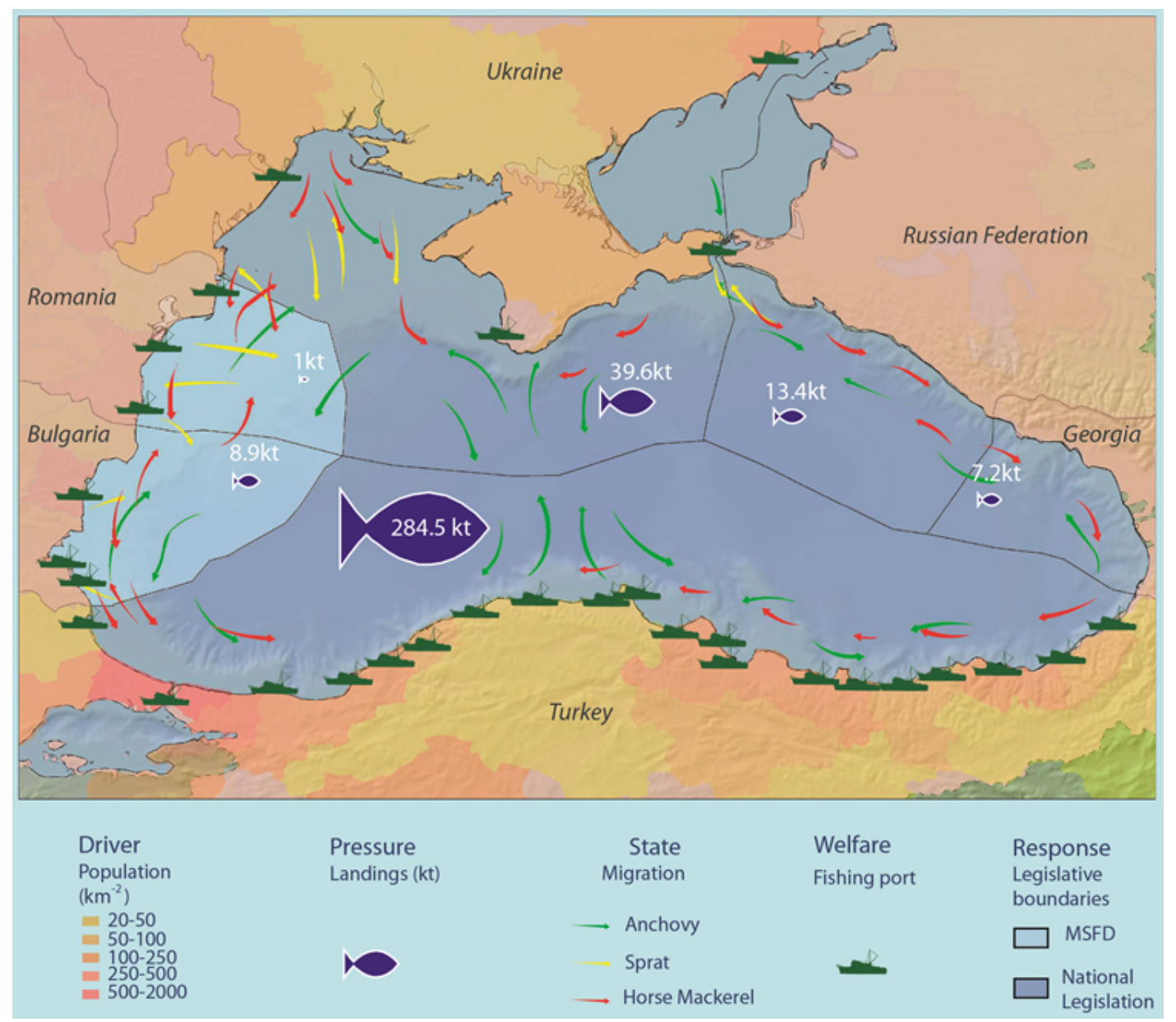

with its neighbors to restore and protect Black Sea habitats, as spawning grounds for example, but no obvious incentive to broker agreements for maintaining stocks as they dominate fisheries and in current circumstances would continue to do so, even if the activity were restricted to their own waters.

The spatial domain over which management of the pressure and state of the stocks is required is larger than, and extends beyond, the spatial domain of European legislation under the MSFD and the EU Common Fisheries Policy. Thus, there is a clear extent mismatch between the European jurisdiction, the pressure, and state of the small pelagic fisheries. Attempts to achieve GEnS and maximum sustainable yield for small pelagic stocks through measures at the EU level clearly cannot be effective until this mismatch is addressed.

\section{DISCUSSION}

At the heart of both of the above examples of environmental problems are trade-offs between the benefits created by economic
Table 1. Status of Black Sea countries in terms of UN Agreements on fisheries management (UNCLOS 2012) illustrating the complexity of achieving regional cooperation on fishing in the Black Sea.

\begin{tabular}{|c|c|c|c|c|}
\hline \multirow[b]{2}{*}{ Country } & \multicolumn{2}{|c|}{$\begin{array}{c}\text { United Nations } \\
\text { Convention on the Law of } \\
\text { the Sea (UNCLOS) }\end{array}$} & \multicolumn{2}{|c|}{$\begin{array}{l}\text { UN Convention on } \\
\text { Straddling and Highly } \\
\text { Migratory Fish Stocks }\end{array}$} \\
\hline & Signed & $\begin{array}{l}\text { Ratified/ } \\
\text { acceded }\end{array}$ & Signed & $\begin{array}{l}\text { Ratified/ } \\
\text { acceded }\end{array}$ \\
\hline Bulgaria & 1982 & 1996 & - & $2006^{\dagger}$ \\
\hline Georgia & - & 1996 & Not signed & \\
\hline Russian & 1982 & 1997 & 1995 & 1997 \\
\hline Federation & & & & \\
\hline Romania & 1982 & 1996 & - & $2007^{\dagger}$ \\
\hline Turkey & Not signed & & Not signed & \\
\hline Ukraine & 1982 & 1999 & 1995 & 2003 \\
\hline
\end{tabular}


sectors (drivers of fisheries and agriculture) and the costs of the environmental state changes caused by these activities. In the case of eutrophication, the costs of improving environmental management in the Danube catchment, to be borne largely by the agricultural sector, must be balanced against the environmental and economic benefits of improving water quality in the northwestern shelf of the Black Sea, as well as similar considerations in the riverine system itself. In the case of the small pelagic fisheries, both the costs (of implementing improved fishing practices) and the benefits (of increased sustainability of the small pelagic fisheries) relate directly to the fishing industry.

Despite holding legal jurisdiction in most of the Danube catchment, and being the major contributor of economic subsidy to the agricultural industry in the area, the European Union to date has not demonstrated the ability to improve agricultural practices at the spatial scales required to address diffuse pollution. This results from the mosaic of national economic and social conditions within the catchment. All EU Member States in the catchment have published their first River Basin Management Plans under the WFD and the European Commission (2012) published its first detailed assessment of these plans. Key findings include:

- Many Member States heavily rely on existing measures under policies such as the Nitrates Directive.

- Some Member States have only a tentative analysis of the links between the pressures from agriculture and the State changes caused with little relation to any proposed measures.

- Where additional measures are proposed many are those that can be supported under the Rural Development Programme of the CAP.

- There is a need to establish clear mandatory baseline requirements for farmers, above which additional support can be given.

Addressing diffuse pollution is key to achieving the marine environmental objectives of the EU both under the WFD and MSFD. The legislative instruments relevant to improved farming practices (WFD, nitrates Directive) are not integrated with the legislative instruments directed at the marine environment. For example the nitrates Directive requires Member States to designate "nitrate vulnerable zones" but when it was developed the legislation did not envisage these areas to cover large agricultural areas and extend over vast areas of continental shelves into the exclusive economic zones of neighbouring states (as is the case in the Black Sea).

Integrating considerations of the benefits from reduced eutrophication in the northwest shelf of the Black Sea with the creation of mandatory baseline requirements for farmers and the distribution of rural development funds under the CAP could provide a financial mechanism improving the EU ability to address diffuse pollution at a fine spatial scale and to mitigate the current grain scale mismatch. This would result in a case of not quite where the "polluter pays" but more where the "polluter doesn't receive a subsidy." Such a response would make the tradeoff between agricultural activity and environmental health explicit at a local level, i.e., internalize the current externality. However, given that the Commission acknowledges the limited extent of the knowledge linking pressures and states in some EU Member States, and the clear economic disparity across the region (Fig. 3), such an approach cannot be taken without improving national capacity in some states to implement reform. Any effective regional strategy must also account for the fact that in poorer nations that are particularly reliant on agriculture, e.g., Moldova, the costs of improved environmental management may be disproportionately onerous.

The lack of a regional fisheries management agreement in the Black Sea results in the tragedy of the commons at an international scale (Hardin 1968) and is compounded by geopolitical tensions. Given the lack of a regional agreement, the benefits of unilateral actions by EU Member States to improve management of small pelagic fisheries may not accrue to the Member States themselves but to Turkish fishers. As with the case of the grain scale mismatch observed for eutrophication, the extent mismatch between EU legislation and fish stock and fishing pressure distribution results in the unequal distribution of costs and benefits. Overcoming this difficulty requires a regional fisheries agreement to be concluded and then enforced.

In spite of the absence of a Regional Fisheries Management Organisation for the Black Sea and an associated concrete framework for scientific cooperation, some progress has been made on developing a rational basis for fisheries management decisions. In 2011, the European Commission's Scientific and Technical Committee for Fisheries (STECF) established an Expert Working Group on Assessment of Black Sea Stocks that has sought to prepare analytical assessments of stocks for sprat, turbot (Scophthalmus maeoticus), anchovy (Engrualis encrasicolus), whiting (Merlangius merlangus), horse mackerel (Trachurus mediterraneus), piked dogfish (Squalus acanthias), and rapana whelk (Rapana venosa; Daskalov and Ratz 2011). Despite imprecise data, these assessments were able to define levels of fishing mortality consistent with maximum sustainable yield for sprat, turbot, anchovy, and whiting, a level of exploitation that is broadly accepted as the primary indicator of GEnS for commercial fisheries descriptor (3) under the MSFD. The General Fisheries Commission for the Mediterranean has also established an ad hoc working group on the Black Sea that held its first meeting in Romania in January 2012 (GFCM Secretariat 2012) and recommended a road map to help GFCM and countries to clearly identify areas of cooperation and technical assistance in fisheries science.

There has been no recent comprehensive study of the current value of the fishery, and the potential socioeconomic costs and benefits of achieving GEnS in the Black Sea. Therefore, in parallel with the emergence of a better understanding of the potential yields of the fisheries, and in particular identification of the reference levels for several key fish stocks, there is now an opportunity for an updated socioeconomic analysis of the costs and benefits of regional fisheries management organization. Goulding et al. (2014) present the first step in this process, an economic assessment of the potential benefits of a Black Sea fishery managed toward maximum sustainable yield. 
Recognition of the potential contribution of well-managed fisheries to the economies of Black Sea riparian states and their coastal regions based on such an analysis, and viewing fisheries management measures as potential investments could inform the ongoing political discussions on a joint management approach on fisheries management, independent of the geopolitical interests expressed in other regional management fora.

Understanding the scale-mismatches and social aspects of the system may help to direct our institutional responses more efficiently toward improving management of the Black Sea but they are not the only challenge to achieving good environmental status in the region. Significant ecological characteristics of the Black Sea and its recovery still provide major research challenges. Oguz et al. (2012) describe a spatial asymmetry in the recovery of the Black Sea from overfishing, with southern waters recovering more rapidly than those of the northwest shelf.

Recovery from eutrophication has also been partial. Although nutrient loads and phytoplankton blooms have declined in the northwest shelf, the food web has not returned to its previous structure and significant flow now diverted to the jelly component of the food web (Oguz and Velikova 2010). Systematic collection of time series data is essential in assessing the ecological recovery of the Black Sea and this also requires a solid institutional cooperation at the appropriate spatial scales.

\section{CONCLUSIONS}

The analysis presented above illustrates how a systematic approach to the analysis of scale mismatch can provide a useful framework for understanding problems in the management of social-ecological systems. Our classification of mismatches developed from Cumming et al. (2006) has the benefit of being integrated with the tried and tested DPSWR framework which, when combined with the decision space analysis maps, has the potential to communicate complex issues of scale and to be more broadly applied in practical management fora.

Our analysis using this classification has illustrated two different kinds of scale mismatch: a grain mismatch caused by the inability to manage activities at a local scale and an extent mismatch caused by a lack of regional cooperation resulting from the geopolitical tensions in the region. What is common to both cases examined above is that those groups bearing the costs of improved environmental management are not the same groups as those experiencing the benefits of the improved environmental management. Identification of scale mismatch helps to target the potential solution in terms of developing and enhancing governance structures at the appropriate scales.

Achieving GEnS in EU waters for the commercial fisheries and eutrophication descriptors of the MSFD in the Black Sea is subject to severe constraints. Within the Danube catchment it is important to stress that delivering the environmental objectives of the Black Sea depends upon the full implementation of a range of EU law other than the MSFD. The analysis in this paper has focused on measures on agriculture within the Water Framework Directive (WFD), but measures need to be taken on other sources of pollution and specific Directives, such as on Urban Waste Water Treatment, Nitrates and Industrial Emissions, need to be fully implemented. Thus pressure on the catchment states to ensure full compliance is needed, such as by the European Commission and stakeholders within those Member States.
With regard to other littoral states, Bulgaria and Romania need to communicate their analyses of the relative importance of different pressures affecting GEnS arising from activities of those states, seeking bilateral or multilateral solutions to those pressures, where possible highlighting the economic case for addressing those pressures. Historic experience has shown that reaching such agreements is difficult.

Addressing these issues requires improved governance. Within Bulgaria and Romania management structures need fully to integrate MSFD and WFD assessments, measures, and planning. Governance changes are also needed fully to integrate the economic cases for controls of pressures. This becomes even more evident in seeking agreements with countries either in the Danube catchment or other littoral states of the Black Sea. The limited ability of the Black Sea Commission to be effective across a range of issues is of concern, although agreement within the Commission may be accelerated if the economic case for change is made.

Responses to this article can be read online at: http://www.ecologyandsociety.org/issues/responses. $\mathrm{php} / 6707$

\section{Acknowledgments:}

The research leading to these results has received funding from the European Community's Seventh Framework Programme [FP7/2007-2013] under grant agreement number 226675. The KnowSeas project is affiliated with LOICZ and LWEC. We are grateful to the two anonymous referees for their helpful suggestions.

\section{LITERATURE CITED}

Atkins, J. P., D. Burdon, M. Elliott, and A. J. Gregory. 2011. Management of the marine environment: integrating ecosystem services and societal benefits with the DPSIR framework in a systems approach. Marine Pollution Bulletin 62:215-226. http:// dx.doi.org/10.1016/j.marpolbul.2010.12.012

Black Sea Commission (BSC). 2008. State of the environment of the Black Sea (2001 - 2006/7). T. Oguz, editor. Publications of the Commission on the Protection of the Black Sea Against Pollution (BSC) 2008-3, Istanbul, Turkey.

Black Sea Commission (BSC). 2009. Implementation of the strategic action plan for the rehabilitation and protection of the Black Sea. Publications of the Commission on the Protection of the Black Sea Against Pollution (BSC), Istanbul, Turkey.

Bodeanu, N. 2002. Algal blooms in Romanian Black Sea waters in the last two decades of the 20th century. Recherche Marines $34: 7-22$.

Borja, Á., I. Galparsoro, O. Solaun, I. Muxika, E. M. Tello, A. Uriarte, and V. Valencia. 2006. The European Water Framework Directive and the DPSIR, a methodological approach to assess the risk failing to achieve good ecological status. Estuarine, Coastal and Shelf Science 66:84-96. http://dx.doi.org/10.1016/j. ecss.2005.07.021 
Caddy, J. F. 1992. Rehabilitation of natural resources. Environmental management and protection of the Black Sea. Technical Experts Meeting, 20-21 May, Constanta, Romania.

Cash, D. W., W. Adger, F. Berkes, P. Garden, L. Lebel, P. Olsson, L. Pritchard, and O. Young. 2006. Scale and cross-scale dynamics: governance and information in a multilevel world. Ecology and Society 11(2): 8. [online] URL: http://www.ecologyandsociety. org/vol11/iss2/art8/

Center for International Earth Science Information Network (CIESIN), Columbia University, International Food Policy Research Institute (IFPRI), The World Bank, and Centro Internacional de Agricultura Tropical ( CIAT). 2011. Global Rural-Urban Mapping Project, Version 1 (GRUMP): Population Density Grid. NASA Socioeconomic Data and Applications Center (SEDAC), Palisades, New York, USA. [online] URL: http://sedac.ciesin.columbia.edu/data/set/grump-v1-population-density

Cociasu, A., L. Dorogan, C. Humborg, and L. Popa. 1996. Longterm ecological changes in Romanian coastal waters of the Black Sea. Marine Pollution Bulletin 32:32-38. http://dx.doi. org/10.1016/0025-326X(95)00106-W

Commission of the European Communities. 1991a. Urban Wastewater Treatment Directive, 91/271/EEC. Commission of the European Communities, Brussels, Belgium.

Commission of the European Communities. 1991b. Nitrates Directive, 91/676/EEC. Commission of the European Communities, Brussels, Belgium.

Cooper, P. 2013. Socio-ecological accounting: DPSWR, a modified DPSIR framework, and its application to marine ecosystems. Ecological Economics 94:106-115. http://dx.doi. org/10.1016/j.ecolecon.2013.07.010

Cumming, G. S., D. H. M. Cumming, and C. L. Redman. 2006. Scale mismatches in social-ecological systems: causes, consequences, and solutions. Ecology and Society 11(1): 14. [online] URL: http://www.ecologyandsociety.org/vol11/iss1/ $\underline{\operatorname{art14/}}$

Daskalov, G., and H. J. Ratz. 2011. Scientific, Technical and Economic Committee for Fisheries (STECF), Opinion by written procedure: Assessment of Black Sea Stocks (STECFOWP-11-06). EUR 25020 EN - 2011. Publications Office of the European Union, Luxembourg. [online] URL: http://stecf.jrc.ec. europa.eu/documents/43805/218009/2011-11 OWP+11-06+-+Black+ Sea+Stock+Assessments JRC67414.pdf

Duzgunes, E., and N. Erdogan. 2008. Fisheries management in the Black Sea countries. Turkish Journal of Fisheries and Aquatic Sciences 8:181-192.

European Commission. 2000. Directive 2000/60/EC of the European Parliament and of the Council of 23 October 2000 establishing a framework for Community actions in the field of water policy. Official Journal of the European Communities L327, 1.22.12.2000.

European Commission. 2008. Directive 2008/56/EC of the European Parliament and of the Council of 17 June 2008 establishing a framework for Community actions in the field of marine environmental policy (Marine Strategy Framework
Directive). Official Journal of the European Communities L164/19 25.06.2008.

European Commission. 2012. Commission Staff Working Document accompanying the document Report to the European Parliament and the Council on the implementation of the Water Framework Directive (2000/60/EC) River Basin Management Plans (COM(2012)670). SWD(2012)379, 14.11.2012. European Commission, Brussels, Belgium.

Food and Agriculture Organization (FAO). 2012. Fertilizer consumption data. FAO, Rome, Italy. http://faostat3.fao.org/ faostat-gateway/go/to/browse/E/EF/E

General Fisheries Commission for the Mediterranean (GFCM) Secretariat. 2012. First meeting of the GFCM ad hoc Working Group on the Black Sea. Constanta, Romania, 16-18 January 2012, Background Document on the Black sea Fisheries, Preliminary Version. GFCM, Rome, Italy. [online] URL: http://151.1.154.86/ GfcmWebSite/SAC/WGBS/2012/GFCM-Background-Doc-BlackSeaFisheries.pdf

Goulding, I. C., K. A. Stobberup, and T. O'Higgins. 2014. Potential economic impacts of achieving good environmental status in Black Sea fisheries. Ecology and Society 19(3): 32. http:// dx.doi.org/10.5751/ES-06817-190332

Hardin, G. 1968. The tragedy of the commons. Science 162:1243-1248. http://dx.doi.org/10.1126/science.162.3859.1243

Henle, K., W. Kunin, O. Schweiger, D. S. Schmeller, V. Grobelnik, Y. Matsinos, J. Pantis, L. Penev, S. G. Potts, I. Ring, J. Simila, J. Tzanopoulos, S. van den Hove, M. Baguette, J. Clobert, L. Excoffier, E. Framstad, M. Grodzinska-Jurczak, S. Lengyel, P. Marty, A. Moilanen, E. Porcher, D. Storch, I. Steffan-Dewenter, M. T. Sykes, M. Zobel, and J. Settele. 2010. Securing the conservation of biodiversity across administrative levels and spatial, temporal, and ecological scales. Gaia 19:187-193.

Hey, E., and L. D. Mee. 1993. Black Sea: The Ministerial Declaration, an important step. Environmental Policy and Law 23:215-220.

International Commission for the protection of the Danube river (ICPDR). 2007. Joint action program final implementation report. ICPDR, Vienna, Austria.

International Commission for the protection of the Danube river (ICPDR). 2009. Danube River Basin District Management plan. Part A-basin wide overview. ICPDR, Vienna, Austria.

International Commission for the protection of the Danube river (ICPDR) 2012. Interim report on the implementation of the joint program of measures in the DRBD. ICPDR, Vienna, Austria.

Ivanov, L. S., and R. J. H. Beverton. 1985. The fisheries resources of the Mediterranean. Part two: Black Sea. FAO Studies and Reviews, Volume 60. Food and Agriculture Organization of the United Nations, Rome, Italy.

Knowler, D. 2008. Socio-Economic Pressures and Impacts. Chapter 11 in State of the environment of the Black Sea (2001 2006/7). T. Oguz, editor. Publications of the Commission on the Protection of the Black Sea Against Pollution (BSC) 2008-3, Istanbul, Turkey. [online] URL: http://www.blacksea-commission. org/ publ-SOE2009-CH11.asp 
Knudsen, S., M. Zengin, and M. H. Koçak. 2010. Identifying drivers for fishing pressure. A multidisciplinary study of trawl and sea snail fisheries in Samsun, Black Sea coast of Turkey. Ocean and Coastal Management 53:252-269. http://dx.doi.org/10.1016/ j.ocecoaman.2010.04.008

Kok, K., and T. A. Veldkamp. 2011. Scale and governance: conceptual considerations and practical implications. Ecology and Society 16(2): 23. [online] URL: http://www.ecologyandsociety. org/vol16/iss2/art23/

Langmead, O., A. McQuatters-Gollop, L. D. Mee, J. Friedrich, A. J. Gilbert, M.-T. Gomoiu, E. L. Jackson, S. Knudsen, G. Minicheva, and V. Todorova. 2009. Recovery or decline of the northwestern Black Sea: a societal choice revealed by socioecological modelling. Ecological Modelling 220:2927-2939. http:// dx.doi.org/10.1016/j.ecolmodel.2008.09.011

Mee, L. D. 2006. Reviving dead zones. Scientific American 295:79-85. http://dx.doi.org/10.1038/scientificamerican1106-78

Mee, L. D., J. Friedrich, and M. T. Gomoiu. 2005. Restoring the Black Sea in times or uncertainty. Oceanography 18:100-111. http://dx.doi.org/10.5670/oceanog.2005.45

Oguz, T., E. Akoglu, and B. Salihoglu. 2012. Current state of overfishing and its regional differences in the Black Sea. Ocean and Coastal Management 58:47-56. http://dx.doi.org/10.1016/j. ocecoaman.2011.12.013

Oguz, T., and V. Velikova. 2010. Abrupt transition of the northwestern Black Sea shelf ecosystem from a eutrophic to an alternative pristine state. Marine Ecology Progress Series 405:231-242. http://dx.doi.org/10.3354/meps08538

O'Higgins, T., and E. Roth. 2011. Integrating the Common Fisheries Policy and the Marine Strategy for the Baltic. Discussion of spatial and temporal scales in the management and adaptation to climate change. Pages 275-294 in G. Schernewski, editor. Climate change and Baltic coasts. Springer, Verlag, Berlin, Germany.

Özturk, B. 2013. Some remarks of illegal, unreported and unregulated (IUU) fishing in the Turkish part of the Black Sea. Journal of the Black SealMediterranean Environment 19:256-267.

Ramankutty, N., A. T. Evan, C. Monfreda, and J. A. Foley. 2008. Farming the planet: 1. Geographic distribution of global agricultural lands in the year 2000. Global Biogeochemical Cycles 22:GB1003. http://dx.doi.org/10.1029/2007GB002952

Suárez de Vivero, J. L., and J. C. R. Mateos. 2006. Maritime Europe and EU enlargement. A geopolitical perspective. Marine Policy 30:167-172. http://dx.doi.org/10.1016/j.marpol.2004.11.002

Taylor, T., and A. Longo. 2010. Valuing algal bloom in the Black Sea Coast of Bulgaria: a choice experiments approach. Journal of Environmental Management 91:1963-1971 http://dx.doi. org/10.1016/j.jenvman.2010.04.007

United Nations Convention on the Law of the Sea (UNCLOS). 2012. Status of the United Nations Convention on the Law of the Sea, of the Agreement relating to the implementation of Part XI of the Convention and of the Agreement for the implementation of the provisions of the Convention relating to the conservation and management of straddling fish stocks and highly migratory fish stocks. Table recapitulating the status of the Convention and of the related Agreements, as at 6 November 2012. UN, New York, New York, USA. http://www.un.org/Depts/los/convention_agreements/ convention_overview_fish_stocks.htm

Veldkamp, A., N. Polman, S. Reinhard, and M. Slingerland. 2011. From scaling to governance of the land system: bridging ecological and economic perspectives. Ecology and Society 16(1): 1. [online] URL: http://www.ecologyandsociety.org/vol16/iss1/ $\underline{\operatorname{art1/}}$

Vlad, L. B., G. Hurduzeu, and A. Josan. 2009. Geopolitical reconfigurations in the Black Sea area at the beginning of the $21^{\text {st }}$ century. Romanian Review of Political Geography 11:65-76.

World Bank. 2013. GDP (current US\$). World Bank, Washington, D.C., USA. http://data.worldbank.org/indicator/ NY.GDP.MKTP.CD 